\title{
Cortaderia spp. in New Zealand: patterns of genetic variation in two widespread invasive species
}

\author{
Gary J. Houliston* and Dagmar F. Goeke \\ Landcare Research, PO Box 69040, Lincoln, New Zealand 7640 \\ *Author for correspondence (Email: houlistong@landcareresearch.co.nz)
}

Published online: 2 December 2016

\begin{abstract}
Cortaderia selloana (pampas grass) and C. jubata (purple pampas grass) are both invasive in New Zealand. Cortaderia selloana is found throughout most of the country, whereas C. jubata is restricted to the North Island and the northern South Island. We examine the genetic variation present in each of the species, and compare this to the findings of an earlier study that analysed the variation in invasive C. jubata plants from New Zealand. Cortaderia selloana is comprised of two main genetic groupings in New Zealand, one of which is more common than the other. The distribution of these two genetic groupings is discussed with respect to introduction history. Cortaderia jubata has considerably more genetic variation than expected, higher than estimated by a previous work. We discuss these results in the context of Cortaderia invasion in New Zealand and how this may impact on the design of a biocontrol programme.
\end{abstract}

Keywords: Cortaderia; genetics; invasion; microsatellites; weed

\section{Introduction}

Cortaderia Stapf (Gramineae) is a genus of large perennial tussocks originating in South America. It is regarded as being made up of 19 species, although due to the lack of a comprehensive recent revision, the actual number of species in the genus is uncertain (Linder et al. 2010). Within the genus there are some species that have become invasive outside of their native range, particularly in New Zealand, the United States and South Africa (Robinson 1984; Ahmad et al. 2006; Edgar \& Connor 2010). Two Cortaderia species are invasive in New Zealand, C. selloana (Schult. \& Schult. f.) Asch. \& Graebn. and C. jubata (Lemoine) Stapf (Edgar $\&$ Connor 2010). Until recently (Linder et al. 2010), seven native species of large tussock were regarded also as being in Cortaderia (since moved to a new genus, Austroderia). The two species differ in their breeding system, with $C$. selloana being gynodioecious, albeit with very low seed set in hermaphrodites making it functionally almost dioecious, whereas $C$. jubata is an autonomous apomict (produces seeds via parthenogenesis without the need for pollination).

Cortaderia selloana (pampas grass; $2 n=8 X=72$ ) was first introduced into New Zealand about 1876 as a fodder species (Knowles \& Ecroyd 1985), and has subsequently been used as both an ornamental and shelter species (Grimmet 1935). Cortaderia selloana was sold and grown extensively through the 1930s and 40s, and was still being evaluated as a valuable species in the 1950s (Jacques 1957; Knowles \& Ecroyd 1985). During this time several 'strains' were developed by taking vegetative clones from existing plants, collecting seed, or even from experimental crosses. While some 'strains' or varieties were given names, the origins of most were unclear. The use of C. selloana as a fodder decreased sharply in the 1950s as land improvement became more common and better yielding pasture species were discovered. By the 1980s, C. selloana was recognised as being invasive, especially in plantation forestry, and by the early 2000s was having considerable impacts on primary productivity and the environment as a weed (Harris \& Skilton 2007).
Cortaderia jubata (jubata grass; $2 n=12 X=108$ ) is naturalised in New Zealand also from South America, and is a problem weed of forestry areas. Cortaderia jubata is an escape from ornamental plantings, first recorded in the 1960s as C. atacamensis (Knowles \& Ecroyd 1985). Unlike C. selloana, as an apomict it has only female inflorescences, and is often identified by the purple hue of the florets, although this character is not completely reliable.

The cost of control of $C$. selloana and $C$. jubata in New Zealand is substantial at $\$ 4000-\$ 6000$ per hectare on the conservation estate, and it is also a considerable problem weed of roadsides, proving difficult to control with herbicides (Popay et al. 2003). Due to the cost and the widespread nature of the two species, a feasibility study on the biocontrol of $C$. selloana and C. jubata in New Zealand has been undertaken. Part of this study involved characterising the genetic variation present in introduced Cortaderia in New Zealand, to inform the range of material that would need to be searched for in the native range to allow accurate bio-prospecting for control agents. An earlier study by Okada et al. (2009) showed that some New Zealand individuals of C.jubata are similar to plants found in Ecuador and Peru, although the origin or amount of variation of $C$. selloana in New Zealand has not been assessed. What is clear is that $C$. jubata has undergone a strong founder effect during naturalisation, with most of the introduced range consisting of a single genetic clone. Cortaderia selloana may have undergone a similar process during naturalisation, although it is unknown how severe an effect this would have had on genetic variation due to it reproducing sexually and having multiple introductions. This study aims to determine whether a wider range of $C$. jubata samples from New Zealand has similar levels of genetic variation to those included in the Okada et al. (2009) study from both New Zealand and California, and whether $C$. selloana has also undergone a strong founder event during naturalisation in New Zealand. As these species differ substantially in breeding system, but have both been successful invaders in New Zealand, it is of interest to determine whether we see strong differences in the genetic variation of the invading populations. 
Materials and methods

\section{Plant material and DNA extraction}

Leaf samples of 582 invasive Cortaderia samples were sourced from sites across the two main islands of New Zealand (Fig. 1, Table S1 in Supplementary Material). All samples were dried in silica gel immediately after sampling or collected from the Allan Herbarium (CHR) in Lincoln, New Zealand. The samples collected cover most of the known range of Cortaderia in New Zealand, especially for C. jubata. For C. selloana our sampling is more comprehensive in the North Island, where it is more commonly invasive; in the South Island it is more often restricted to plantings and shelter belts.

DNA was extracted using either an iNtRON plant DNA extraction kit (iNtRON Biotechnology, Seongnam, South Korea) or the Maxwell@ 16 Tissue DNA purification kit (Promega Corporation, Madison, USA) following the manufacturers' instructions. DNA quality and quantity were determined using a Nanodrop ND-1000 spectrophotometer (Nanodrop Technologies, Wilmington, Kentucky, USA).

\section{Polymerase Chain Reaction amplification and microsatellite genotyping}

Eight microsatellite primers amplifying nine polymorphic microsatellite loci published for $C$. selloana and $C$. jubata were used for genotyping (Ahmad et al. 2006; Okada et al. 2009) (Table 1). Polymerase chain reaction (PCR) conditions were optimised and the forward primers were labelled at the 5 '-end with different fluorescent dyes (6-FAM, NED or HEX) to allow multiplexing for genotyping.

Polymerase chain reactions were performed with final concentrations of $1 \mathrm{U}$ of iTaq DNA polymerase (iNtRON Biotechnology), $1 \times$ PCR buffer, $1.5 \mathrm{mM} \mathrm{MgCl}_{2}, 40 \mu \mathrm{g} / \mathrm{mL}$ BSA(NEB), $208 \mu \mathrm{M}$ dNTP-Mix, 167 nM 5'-labelled forward primer, $167 \mathrm{nM}$ reverse primer, and $10-50 \mathrm{ng}$ of DNA in a total reaction volume of $15 \mu \mathrm{L}$, adjusted with filtered $(0.22 \mu \mathrm{m})$ and autoclaved Millipore $\mathrm{H}_{2} 0$. Thermocycling was conducted on Bioer GenePro thermocylers: $94^{\circ} \mathrm{C}$ for $4 \mathrm{~min}, 35$ cycles of $94^{\circ} \mathrm{C}$ for $30 \mathrm{~s}, 55^{\circ} \mathrm{C}$ for $30 \mathrm{~s}, 72^{\circ} \mathrm{C}$ for $45 \mathrm{~s}$, and a $72^{\circ} \mathrm{C}$ final extension period for $20 \mathrm{~min}$. Ten $\mu \mathrm{L}$ were used to view the amplification products on $2.5 \%$ agarose gels.
Samples $(1 \mu \mathrm{L})$ of the resulting amplified DNAs were prepared by adding $9 \mu \mathrm{L}$ of Hi-Di formamide (Applied Biosystems, Carlsbad, California, USA) and $1 \mu \mathrm{L}$ of ROX-labelled size standard (Applied Biosystems), before being separated on an ABI3730 Genetic Analyzer (Applied Biosystems).

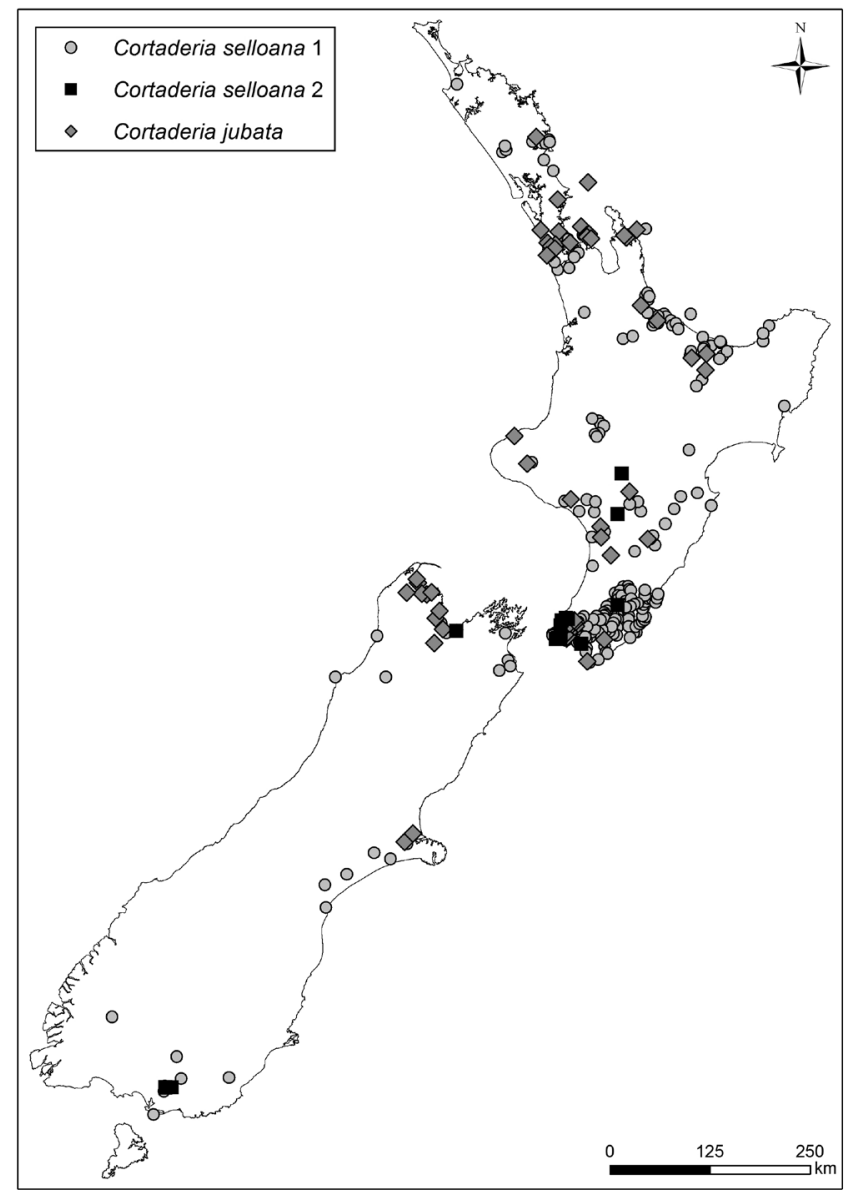

Figure 1. The distribution of the Cortaderia samples included in this study, labelled by species and showing the two different types of C. selloana.

Table 1. The number of markers per locus, by species. Numbers of alleles per individual in parentheses refer to a single individual with that number of alleles per locus. Private alleles are those only found in one or the other species included in the study. SSR marker labels refer to Ahmed et al. (2006).

\begin{tabular}{lllllll}
\hline \multicolumn{3}{c}{ C. selloana } & & \multicolumn{2}{l}{ C. jubata } \\
\hline SSR marker & $\begin{array}{l}\text { Allele size } \\
\text { range (bp) }\end{array}$ & $\begin{array}{l}\text { Putative alleles / } \\
\text { (private alleles) }\end{array}$ & $\begin{array}{l}\text { Number of } \\
\text { alles per } \\
\text { individual }\end{array}$ & $\begin{array}{l}\text { Allele size } \\
\text { range (bp) }\end{array}$ & $\begin{array}{l}\text { Putative alleles / } \\
\text { (private alleles) }\end{array}$ & $\begin{array}{l}\text { Number of alleles } \\
\text { per individual }\end{array}$ \\
Cor-7 & $236-272$ & $15(8)$ & $1-2$ & $244-269$ & $7(0)$ & $1-2$ \\
Cor-11 & $166-223$ & $12(6)$ & $1-4$ & $169-223$ & $7(1)$ & $1,3(2)$ \\
Cor-36 & $335-399$ & $16(12)$ & $1-2(3)$ & $352-373$ & $4(0)$ & $2-3$ \\
Cor-43 & $105-196$ & $18(15)$ & $1-3$ & $101-150$ & $6(3)$ & $1-2$ \\
Cor-46 & $209-240$ & $3(2)$ & $1(3)$ & $209-211$ & $2(1)$ & 2 \\
Cor-47 & $233-243$ & $5(2)$ & $1-2(3)$ & $233-243$ & $4(1)$ & $2-3$ \\
Cor-49 & $115-130$ & $6(4)$ & $1-2$ & $120-124$ & $2(0)$ & $1-2$ \\
Cor-56-1 & $199-204$ & $5(3)$ & $1-2(3)$ & $199-201$ & $2(0)$ & 2 \\
Cor-56-2 & $222-228$ & $6(3)$ & $1-2$ & $224-226$ & $3(0)$ & $2(1)$ \\
\hline
\end{tabular}




\section{Data analysis}

Fragments were sized and scored using GeneMarker v.2.2.0 (SoftGenetics, USA). As per the studies of Ahmad et al. (2006) and Okada et al. (2009), scoring was modified from conventional microsatellite analysis to account for the high ploidy within Cortaderia species. Scores from both species were scored as binary characters and interpreted as dominant markers, due to our inability to assign dosage to the different markers, and because some material was collected from plants not flowering and therefore could not be assigned morphologically to one species or the other. The number of peaks per locus for each of the species is shown in Table 1.

Summary statistics and AMOVA (Analysis of Molecular Variance) were prepared in GenAlEx version 6.5 (Peakall \& Smouse 2012) (Table 3), and a PCoA plot prepared from the complete dataset including both species, using MVSP (MultiVariate Statistical Program) and Gower General Similarity (version 3.22, Kovach Computing Ltd). Both AMOVA were performed with 1000 iterations for each of the datasets. Significance was not recorded for the AMOVA due to these being based on divisions recovered from an assignment analysis (STRUCTURE) (Meirmans 2015). STRUCTURE v2.3.4 (Falush et al. 2003) was used to examine the optimal number of assignment classes within each of the species, using the admixture model. Burn-in was 200 000, followed by a run of 350000 iterations, with 10 runs performed for each value of $K$. $K$ values ranged from $1-5$, and no prior population data were included in the model. Results are shown in Figures 1a and 1b. The optimal $K$ value was selected following the Evanno method (Evanno et al. 2005) as implemented in STRUCTURE HARVESTER (Earl \& von Holdt 2012). The two species were initially run as a single dataset, with $C$. selloana and C. jubata then being run individually. STRUCTURE uses Bayesian probability to assign individuals to a population (or populations in the case of admixed individuals) based on the frequencies of alleles in each of the assumed populations, with the number of populations denoted by $K$. Individuals that have high genetic similarity or that have exchanged genetic material recently will be clustered together, and assigned to provide the highest probablility of clustering for that particular value of $K$.

\section{Results}

In total, 582 individuals from New Zealand were successfully genotyped: 60 from the South Island (12 C. jubata and $48 C$. selloana) and 522 from the North Island (84 C. jubata and 438 C. selloana) (Fig. 1). Markers were robust with very few markers failing to produce alleles for almost all individuals. While the markers in this study were originally designed to be bi-allelic (Ahmad et al. 2006; Okada et al. 2009), we found that we commonly amplified more than two alleles per locus even in C. selloana. Therefore, we scored all loci as dominant, with no interpretation of dosage. While this does reduce the information on heterozygosity from our data, this reduction is of more importance to applications such as paternity analysis than population assignment. The number of alleles scored per individual for each of the species for each locus and the total number of alleles per locus and allele size range for each species are shown in Table 1.

The two species of Cortaderia present in New Zealand are readily identified in the dataset, with the variation in $C$. jubata being low compared to $C$. selloana (Table 2). The optimal value of $\mathrm{K}$ from the STRUCTURE analysis for the data was $K=3$, as determined by STRUCTURE harvester. $K=$ 2 also provided a good fit, resolving $C$. selloana and $C$.jubata, with $K=3$ resolving a further division within $C$. selloana (see Figure S2 in Supplementary Material). Summary statistics for C. jubata, C. selloana (total), and C. selloana by the two STRUCTURE divisions are shown in Table 2. The geographic distributions of the two divisions of $C$. selloana are shown in Figure 1, with the more common type being widespread and the less numerous type having a restricted, yet disjunct range. Further analysis of the $C$. jubata data found that $K=3$ was the best fit, and assignment of individuals within this is shown in Figure S3 (see Supplementary Material).

Summary statistics for each of the species and the two divisions in C. selloana are shown in Table 1. Cortaderia jubata has lower values than $C$. selloana for most of the genetic diversity metrics compared, particularly estimated heterozygosity $(\mathrm{He})$ and the number of alleles per locus $(\mathrm{Na})$ (Table 2). Statistics for the two divisions of the C. selloana samples were similar, especially the number of effective alleles $(\mathrm{Ne})$ and estimated heterozygosity $(\mathrm{He})$. The multi-locus genotypes function in GenAlEx 6.5 identified 31 multi-locus genotypes in $C$. jubata, of which 20 were singletons (11 with at least two identical individuals). By comparison, the outcrossing $C$. selloana had 435 genotypes, with 401 singletons (34 genotypes with at least two identical individuals). AMOVA between $C$. selloana and C. jubata partitioned $59 \%$ of variation among populations, and $41 \%$ within populations. Within $C$. selloana $38 \%$ of variation was among populations, and $62 \%$ within populations.

Table 2. Summary statistics for $C$. selloana and $C$. jubata from New Zealand. For C. selloana, statistics for the two main genetic groups found in New Zealand are also shown: $n$, number of samples; Na, number of alleles; Ne, number of effective alleles; I, Shannon's information index; He, estimated expected heterozygosity; uHe, unbiased estimated expected heterozygosity. Values in parentheses are Standard Errors of the Means.

\begin{tabular}{lllllll}
\hline & $n$ & $\mathrm{Na}$ & $\mathrm{Ne}$ & $\mathrm{I}$ & $\mathrm{He}$ & $\mathrm{uHe}$ \\
\hline C. selloana & 486 & $1.891(0.048)$ & $1.152(0.028)$ & $0.155(0.024)$ & $0.095(0.016)$ & $0.095(0.016)$ \\
C. jubata & 96 & $0.750(0.099)$ & $1.099(0.026)$ & $0.098(0.020)$ & $0.061(0.014)$ & $0.061(0.014)$ \\
Total & 582 & $1.321(0.069)$ & $1.125(0.019)$ & $0.126(0.016)$ & $0.078(0.011)$ & $0.078(0.011)$
\end{tabular}

C. selloana only

\begin{tabular}{lllllll} 
& $n$ & $\mathrm{Na}$ & $\mathrm{Ne}$ & $\mathrm{I}$ & $\mathrm{He}$ & $\mathrm{uHe}$ \\
C. selloana type 1 & 460 & $1.804(0.062)$ & $1.151(0.029)$ & $0.148(0.024)$ & $0.093(0.017)$ & $0.093(0.017)$ \\
C. selloana type 2 & 26 & $0.913(0.103)$ & $1.145(0.027)$ & $0.154(0.023)$ & $0.094(0.015)$ & $0.096(0.016)$ \\
\hline
\end{tabular}


The three STRUCTURE divisions are shown in the PCoA plot (Fig. 2). The first axis explains $31.0 \%$ of the variation, and the second $6.9 \%$. Cortaderia jubata forms a single group, with the core $C$. selloana group and the second $C$. selloana group also being clearly distinguished on the plot. Variation in C. selloana is much greater than that in C. jubata, as also seen in the summary statistics.

\section{Discussion}

Cortaderia in New Zealand has become a significant weed due to its propensity to invade both native and non-native systems, and because its control consumes considerable resources. The aim of this study was to understand the genetic variation within Cortaderia species in New Zealand to better infer the pattern of invasion, with an eye towards possible biocontrol solutions. The two species of Cortaderia are readily distinguishable genetically, but the amount of genetic variation present in each differs markedly. This pattern is not surprising given the difference in breeding system of the two species (Connor 1974). An earlier study on the genetics of invasive $C$. jubata from around the world (Okada et al. 2009) suggested that $C$. jubata in New Zealand was almost clonal; a finding consistent with its apomictic reproductive mode. This present study included substantially more samples of $C$. jubata than that of Okada et al. (2009) to determine if this conclusion was robust. Genetic diversity in the current study is considerably higher than in Okada et al. (2009), where from 16 individuals they found a total of five multi-locus genotypes, and considerably higher diversity than in other parts of the invasive range (233 samples from California comprised 8 genotypes, while 33 samples from Hawai' $i$ were a single genotype). From the 96 samples assigned to C. jubata in the current study, we found 31 multi-locus genotypes ( 11 of which comprised of two or more individuals), a similar proportion to the Okada et al. (2009) study, although surprisingly high for a species that is believed to be obligately apomictic. Our samples came from a broader range of sites from across New Zealand, although this does not completely explain the high number of multi-locus genotypes present, as Okada et al. (2009) found only 11 from all of the samples in the introduced range (Table 1). The proportion of genotypes to samples observed in this study is comparable to $C$. jubata in the native range (77 samples with 26 unique genotypes) (Okada et al. 2009). Further investigation into the reproduction of $C$. jubata may be warranted, as it is unlikely that we would see this level of genetic diversity in a purely apomictic species, especially one that is a recent invader. This result would make it seem highly unlikely that $C$. jubata has undergone any bottlenecking or reduction in genetic variation as a result of introduction. While the variation present in $C$. jubata is considerably less than observed in C. selloana, this is not surprising as the two species have different breeding systems.

STRUCTURE analysis indicates that there are three main groups of genotypes within the diversity of $C$. jubata in New Zealand. The high diversity in New Zealand has several possible explanations. Whereas plantings of $C$. jubata in California were for landscape or amenity purposes, Cortaderia in New Zealand has historically been used as a fodder species $(C$. selloana) and as an ornamental (C. jubata), and therefore it is likely there have been numerous introductions. It is also possible that some early records of $C$. selloana actually refer to both species, as the taxonomic treatment of these species has been problematic in New Zealand. Cortaderia jubata was often referred to as $C$. atacamensis, a species found in Northern Argentina, and some early reports of hybrids between C. selloana and the native Austroderia were most likely $C$. jubata (Connor 1965). The complex introduction history of Cortaderia in New Zealand and the numerous uses of the plant in many different habitats make it unsurprising that variation is higher than in other parts of the introduced range.

Genetic variation in Cortaderia selloana is notable in that there are two well differentiated genetic groups in the dataset, one of which is far more numerous in the environment than the other. These groupings are supported by Bayesian clustering methods, PCoA, and AMOVA, and would appear to be robust. These two groups of plants flower at different times of the year (Daniel Than, Richard Toft, pers. comm.), but otherwise cannot be readily identified morphologically. Nonsynchronous flowering times likely represent a reproductive barrier between the two groups. The less common type of $C$. selloana is found across a range of locations in New Zealand; however, it does not seem to be as invasive, at least currently. It is unclear whether this reflects a type that is not as aggressive as most of the C. selloana plants across the rest of the country

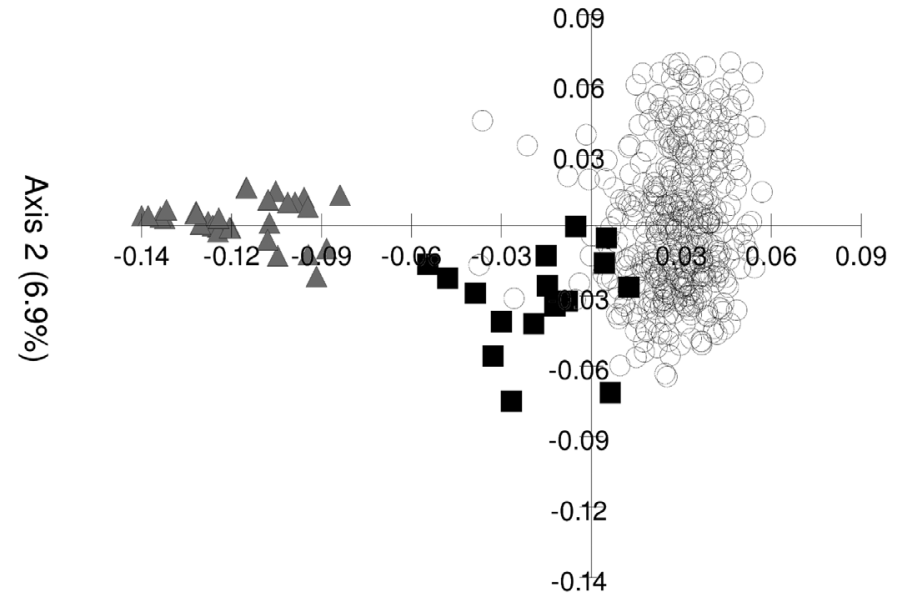

Axis $1(31.0 \%)$
Figure 2. PCoA plot of C. jubata and C. selloana from New Zealand based on dominant scoring of SSR data, showing the two STRUCTURE divisions of C. selloana. 
or a type that has not been grown to the same extent (reduced propagule pressure).

Assuming that these two entities within C. selloana fall within the species concept for this taxon, and we currently have no evidence that this is not the case, it may be that they do represent races within $C$. selloana, with different degrees of weediness. Other studies of invasive species have shown that it is often only a subset of the genetic variation within a species that has the propensity to become weedy (Dekker 2003), and that species per se is not a good predictor of invasive potential (Baker 1965). How these two groups of genotypes vary ecologically is unclear, other than the noted difference in flowering time, and whether differences in performance explain the different frequency of these types in the environment requires further study. It is difficult to interpret this pattern in regard to the literature on the introduction of $C$. selloana into New Zealand (Grimmett 1935; Dunlop \& Coup 1951). These reports often mention different strains or cultivars being used in different areas, although how well characterised these were is unknown. These earlier reports cannot explain the distribution of the two types of $C$. selloana, and it is likely that reproductive and demographic processes have been more important in shaping the variation we see today (Novak \& Mack 2005).

Control of pampas grass in New Zealand is of high interest due to the expense of using herbicides, and the low efficacy of most herbicide applications on the plants (Harris \& Skilton 2007). As a result there has been interest in developing biological control agents for use against Cortaderia. The results of this study would indicate that agents will have to be chosen carefully for best efficacy against the variation that is present in New Zealand within each of these species. Cortaderia jubata is known to have come from Peru and Ecuador (Okada et al. 2007), although variation within C. jubata is higher than found in the earlier study, so further refinement may be required to determine the correct area to search for agents. Cortaderia selloana is also problematic, because there are two distinctly different groups of genotypes in New Zealand, and it will be essential to determine what part of the native range relates to the more common of the two for bio-prospecting for agents. Any agents will also have to be safe against the closely related Austroderia species, so specificity will be critical to achieve control without adverse effects on the native flora.

Understanding the genetic variation in invasive species is important to both understand the process of invasion, and to better explore control options. Cortaderia is an ideal model system for these questions due to the presence of multiple species or genotypes in the introduced range. By comparing the results of the present study to work examining the variation in the native range of Cortaderia, we aim to prospect for biocontrol agents, and assess the risk of the different entities already present in New Zealand.

\section{Acknowledgements}

The authors thank Chris Winks, Daniel Than, Harvey Phillips, Ken Wright, Paul Peterson, Randall Milne, Richard Toft, Dave Moverley and Lindsay Smith for field collections of Cortaderia. Marie Jasienuk and Miki Okada provided advice on optimising the microsatellite markers from their earlier work. Funding was provided by the Sustainable Farming Fund via the Ministry for Primary Industries to Landcare Research.

\section{References}

Ahmad R, Okada M, Firestone JL, Mallek CR, Jasieniuk $\mathrm{M}$ 2006. Isolation, characterization, and evaluation of microsatellite loci for cultivar identification in the ornamental pampas grass Cortaderia selloana. Journal American Society for Horticultural Science 131:499-505.

Baker HG 1965. Characteristics and modes of origin of weeds. In: Baker HG, Stebbins GLeds. The genetics of colonizing species. New York, Academic Press. Pp. 147-172.

Connor HE 1965. Breeding systems in New Zealand grasses. V. Naturalised species of Cortaderia (with appendix by E.J. Beuzenberg). New Zealand Journal of Botany 3: 17-23.

Connor HE 1974. Breeding systems in Cortaderia (Gramineae). Evolution 27: 663-678.

Dekker J 2003. The foxtail (Setaria) species-group. Weed Science 51: 641-656.

Dunlop AA, Coup MR 1951. The nutritive value of pampas grass (Cortaderia selloana). New Zealand Journal of Science and Technology 33: 21-33.

EarlDA, von Holdt BM 2012. STRUCTURE HARVESTER: a website and program for visualizing STRUCTURE output and implementing the Evanno method. Conservation Genetics Resources 4: 359-361.

Edgar E, Connor HE 2010. Flora of New Zealand. Volume V Grasses. 2nd edn. Lincoln, New Zealand, Manaaki Whenua Press. 650 p.

Evanno G, Regnaut S, Goudet J 2005. Detecting the number of clusters of individuals using the software STRUCTURE: a simulation study. Molecular Ecology 14: 26112620.

Falush D, Stephens M, Pritchard JK 2003. Inference of population structure using multilocus genotype data: linked loci and correlated allele frequencies. Genetics 164: 1567-1587.

Grimmett RER 1935. Pampas-grass as fodder. New Zealand Journal of Science and Technology 27: 531.

Harris S, Skilton D 2007. Cost benefit analysis of selected pest organisms. A report prepared for Environment Waikato. Harris Consulting.

Jacques W 1957. Pampas grass (Cortaderia selloana) in New Zealand. Its value and place as a fodder plant. Palmerston North, New Zealand, Keeling and Mundy Ltd. 47 p.

Knowles B, Ecroyd C 1985. Species of Cortaderia (pampas grasses and toetoe) in New Zealand. FRI Bulletin No. 105. Rotorua, New Zealand, Forest Research Institute. 24 p.

Linder HP, Baeza M, Barke NP, Galley C, Humphreys AM, Lloyd K, Orlovich D, Pirie MD, Simon BK, Walsh N, Verboom GA2010. Aclassification of the Danthonioideae (Poaceae). Annals of the Missouri Botanical Garden 97: 306-364.

Meirmans PG 2015. 7 common mistakes in population genetics and how to avoid them. Molecular Ecology 24:3223-3231.

Novak SJ, Mack RN 2005. Genetic bottlenecks in alien plant species: influence of mating systems and introduction dynamics. In: Sax DF, Gaines SD, Stachowicz JJ eds. Exotic species - bane to conservation and boon to understanding: ecology, evolution and biogeography. MA, USA, Sinauer. Pp. 95-122.

Okada M,Ahmad R, Jasienuk M 2007. Microsatellite variation points to local landscape plantings as sources of invasive pampas grass (Cortaderia selloana) populations in California. Molecular Ecology 16: 4956-4971.

Okada M, Lyle M, Jasieniuk M 2009. Inferring the introduction 
history of the invasive apomictic grass Cortaderia jubata using microsatellite markers. Diversity and Distributions 15: 148-157.

Peakall R, Smouse PE 2012. GenAlEx 6.5: genetic analysis in Excel. Population genetic software for teaching and research - an update. Bioinformatics 28: 2537-2539.

Popay I, Timmins SM, McCluggage T 2003. Aerial spraying of pampas grass in difficult conservation sites. Science for Conservation 218. Wellington, New Zealand, Department of Conservation. $18 \mathrm{p}$.

Robinson ER 1984. Naturalized species of Cortaderia (Poaceae) in southern Africa. South African Journal of Botany 3: 343-346.

Editorial board member: Hannah Buckley

Received 8 April 2016; accepted 22 August 2016

\section{Supplementary Material}

Additional supporting information may be found in the online version of this article:

Table S1. Location data and labelling for the samples included in this study.

Figure S2. STRUCTURE plot of the whole dataset including Cortaderia selloana (two divisions - red and blue) and $C$. jubata (one division - green).

Figure S3. STRUCTURE plot for $C$. jubata only, showing $K$ $=3$ as chosen by STRUCTURE Harvester.

Figure S4. STRUCTURE plot for $C$. selloana only, showing $K=2$ as chosen by STRUCTURE Harvester.

The New Zealand Journal of Ecology provides online supporting information supplied by the authors where this may assist readers. Such materials are peer-reviewed and copy-edited but any issues relating to this information (other than missing files) should be addressed to the authors. 